\title{
The Symbols Used in Internet Chatting: A Semiotic Analysis
}

\author{
Sri Mulyani \\ SMA Muhammadiyah Salatiga \\ JI KH Ahmad Dahlan, Sidorejo Lor, Sidorejo, Salatiga, 50712 \\ mulyani01siti@gmail.com
}

\begin{abstract}
The aims of this research is to describe the kind of symbols used on internet chatting. Besides elaborating the relation between the symbol and the signee. And the last one of study is to describe the meaning of the symbols used in internet chatting. Since the research explores the symbols used in the internet chatting, qualitative approach is deemed to be the precise research design. The data obtained are described comprehensively by classifying the symbols, analyzing the representation of the symbols based on semiotic approach, and interpreting the meaning of symbols based on the context of the internet chatting text. The findings show that the symbols consists of number, letter, combination of number and letter, and the emoticons or smiley. The sample of the number, consist of ' 2 ' and ' 4 '. For the letter consist of 'R', ' $U$ ', ' $b$ ', 'Ur', 'ASL', 'btw', and so on. For emoticons consist of ':-)', ':-(', ':-P', ':-D', ‘:-C', ';-)', ‘:- ))', ‘: ’, '|-)', '(-_-)', ‘^ ^^, ‘:-|', and '8-O'. Those symbols have different meaning or references with different interpreters because they can be interpreted in denotative level as signifier or in connotative level as signified.
\end{abstract}

Keywords: symbols, internet, chatting, semiology

\begin{abstract}
Abstrak
Tujuan dari penelitian ini adalah untuk mendeskripsikan macam-macam simbol yang digunakan dalam percakapan di internet. Selain itu, tujuan yang selanjutnya adalah untuk mencari hubungan antara simbol-simbol tersebut dengan para pemakainya. Kemudian, studi berlanjut dengan pendeskripsian makna simbol-simbol yang digunakan dalam internet tersebut. Oleh karena penelitian ini meneliti tentang simbol yang digunakan dalam percakapan internet, maka pendekatan kualitatif adalah metode penelitian yang tepat digunakan dalam studi ini. Data-data yang diperoleh kemudian dideskripsikan secara komprehensif dengan cara mengklasifikasikan simbol-
\end{abstract}

REGISTER, VOL. 2, No. 1, JUNE 2009 
simbol tersebut, menganalisis simbol-simbol yang tersaji berdasarkan pendekatam semiotik, dan kemudian mengartikan makna simbol-simbol tersebut berdasarkan konteks percakapan yang ada di internet. Dari hasil penelitian, didapatkan bahwa simbol-simbol tersebut terdiri atas angka, huruf, kombinasi huruf dan angka, serta emotikon. Sebagai contoh untuk angka, yaitu penggunaan angka ' 2 ' dan ' 4 '. Sedangkan untuk huruf yang digunakan adalah 'R', 'U', 'b', 'Ur', 'ASL', 'btw', dan seterusnya. Untuk emotikon

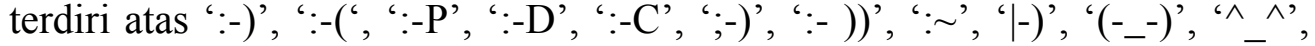
':-|', and '8-O'. Simbol-simbol tersebut mempunyai makna atau referensi yang berbeda dari penafsir yang berbeda-beda pula, karena mereka bisa saja menginterpretasikan hanya pada level denotatif penanda atau pada level konotatif sebagai tertanda.

\section{Kata Kunci: Simbol-Simbol, Internet, Percakapan, Semiologi}

\section{Introduction}

Language plays a very important role as a means of communication. Communication is a process of transmitting information, idea, feeling and attitude from one person to another, in which there is communicator who send a message to communicant in order to influence the other individual's behavior. People do not only predict what other person are going to say but also what they want hear.

There are four elements in communication: source, message, channel, and receiver. The source is the creator of the message. The source can be some persons or a group with a reason of engaging the communication. Meanwhile, the message is the translation of idea into a symbol, each of them as language and gesture. The channel is the medium trough which the message is carried, and the receiver is the person who is the target of communication. In the process of communication, both the sender and receiver must have the same code. When the receiver does not understand a message from sender, there will be an absurd noise code. 
One of the communication instruments in the society is internet. In this globalization era, it takes a big part to make the communication easier. The internet includes millions of computers linked together around the world. Those computers can be at homes, schools, universities, government department, or small or large business. The internet is often described as "a network to networks" because all of smaller networks organizations are linked together into the one giant network. Many people prefer to communicate via internet because it is faster than other communication media without waiting for hours. As technology advantages, more people are conversing over the computer in the real time, using a variety of software tools. The most popular tool is Internet Relay Chat, also known as IRC.

IRC is multi-user chat system where people meet on channels (room or virtual places usually with a certain topic of conversation) to talk in group or individually. Chatting is one of the most popular activities on the internet and involves people from all walks of life and just about all ages to coming together in area where they can join in all variety topics that they are interested in.

In public chat area people is using "username" or "nickname". Users may use something and imaginative names. Most standard name will already be taken and user name is picked in order to directly catch people's eyes. When people are chatting in the rooms or channels, this communication sometimes uses symbols. The symbols such as U, b4, 2, Ur, :-), ;-), :P, are interesting for the writer to investigate.

In line with the symbols used in internet chatting, the writer analyzes these symbols based on semiotic approach. Semiotic is study about signs. Semiotic involves the study not only of what one refers to as signs in everyday speech, but also of anything which stands for something else. In semiotic sense, signs take the form of words, images, sounds, gestures, and 
objects. The writer discusses the symbols of internet chatting by semiotic approach because it makes the writer interested in knowing the knowledge of semiotics and its relation with symbols of internet chatting language.

Based on the problem stated in advance, the objective of the study are to describe the kind of symbols used on internet chatting. The other is to analyze the relation between the symbol and the signee. Last of study is to describe the meaning of the symbols used in internet chatting.

\section{Notion of Semiotics}

Semiology is a science which studies the role of sign as part of social life. Semiotics is one of literary approaches used to analyze certain story or text, use symbol on sign. By using semiotics, we focus our object of study on symbols or sign used in internet chatting. Thus we intend to find out the meaning of those symbols. The term of semiotics, was first introduced by Ferdinand de Saussure the founder of linguistics and semiotics who was born in Swiss in the year of 1857 until 1913 (www.abber.ac.uk). He wrote the book "Cours de linguistique generalle". De Saussure states in his book that in the semiotic study, the signs are very important.

People use many signs or symbol in communication. Semiotics is important because it can help us not to take "reality" for granted as something having a purely objective existence which is independent of human interpretation. It teaches us that reality is a system of signs. The symbols or signs themselves have meaning which are considered multiple rather than

single. A sign is composed of a signifier, the form which the sign take; and the signified; the concept it represent.

\section{Major Principle of Semiotics}

In semiotic study there are major principles as the following:

1. Signifier and signified 
The sign, for Saussure in John Fiske (1990), was a physical object whit a meaning; or, to use his terms, a sign consisted of a signifier and signified. The signifier is the sign's image as we perceive it. The marks on the paper or the sounds in the air; the signified is the mental concept to which it refers. This mental concept is broad common to all members of same cultural who share the language (John Fiske, 1990:44).

2. Denotation and connotation

Denotation and connotation in semiotic are term describing the relationship between the signifier and signified. And an analytic distinction is made between two types signified. Meaning includes both denotation and connotation. Connotation is a sign with derives from the signifier of a denotative sign (so, denotation leads to chain of connotation), the distinction denotation or connotation is an analytic one only.

\section{Slang}

Slang is a language which takes off its coat, spits on its hands - and goes to work (Victoria, 1992:264). One mark of an informal style is the frequent occurrence of slang. Almost everyone use slang on some occasions, but it is not easy to define the word. Slang has been defined as one of those things that everybody can recognize and nobody can define. The use of slang, or colloqueal language, introduces many new words into the language by recombining old word into new meaning.

\section{Internet}

An internet is a more general term informally used to describe any set of interconnected computer networks that are connected by internetworking. (www.wikipedia.com). The internet or simply the "net", is the publicly accessible worldwide system of interconnected computer networks transmit 
data by packet switching using a standardized Internet Protocol (IP) and many others protocols. It is made up of thousand of smaller commercial, academic, domestic and government networks. It is carries various information and service, such as electronic mail, online chat, and the interlinked web pages and other documents of the world wide web.

\section{Research Methodology}

Methodology is the way to get knowledge or to solve the problem, so the method can be called scientific method which identify problem in a research. In this research the writer used qualitative research. Bogdan and Taylor in Moleong (1983) state that qualitative research is a research that presents the descriptive data in the form of written or oral words from observing people behavior. The writer use qualitative research to find and describe the kinds of symbols used in internet chatting language by using written words. The research object is English and indonesian symbol used in internet chatting done by the writer and her friends.

The source of the data or primary data in this research is symbol used in internet chatting themselves as primary data. The method used in collecting data is documentation. The writer take several steps, the first step is the writer connects the IRC website and fulfills the register form on screen, then join to \# cafeislam and \# myquran chanels. Second, the writer chats with friends who are already there, and observe the symbols that by using in chatting. And the last step is by writing the chatting text in corpus data.

In analyzing the data, the writer applies descriptive approach. The steps taken by the writer in analyzing the data are by classifying the symbol, analyzing the representation of the symbols based on semiotic approach, and 
interpreting the meaning of symbols based on the context of the internet chatting text.

\section{Discussion}

The writer presents data by classifying it into four parts, there are: number, letter, number and letter, and the last is punctuation mark or usually called emoticons. This is the part deals with the semiotic analysis, which focuses on the different symbol employed in the internet chatting. These symbol are usually used by chatter of IRC, chatting website on internet. And more are taken from two Islamic channels; there are \#cafeislam, and \#myquran. These symbols are very familiar for the chatters when they chat in internet chatting. The symbols are analyzed as signifier at denotative level and signified at connotative level.

There are thousands of different emoticons and abbreviations, and some of them are used in the internet chatting to communicate with the other people. The basic of emoticons are :-) which means the sender is happy, or the made joke, and :-( which obviously means they are sad or unhappy with what someone has just said.

\section{The Meaning of Symbol}

1. Number
a. Text
: Thank 4 u chatting 2day, $n$ have a great day...
Meaning : thanks for your chatting today, and have a great day...
b. Text : OK, It's up 2 him, I just follow the decision
Meaning : OK, It's up to him, I just follow the decision
c. Text : I just want 2 go there and meet my chatting friend.
Meaning : i just want to go there and meet my chatting friends.
d. Text $\quad$ I'm off 2 day, so I am not go 2 campuss.
Meaning : i'm off today, so I am not go to campuss
e. Text : thanks' 4 helps :-) 
Meaning : Thanks for your helps :-)

Analysis $\quad:$ in the text, there are symbols 4 and 2 as signee. In this analysis the chatters use the sound concept 2 (two) (tu:) to replace the word to (tu:) and $\underline{4 \text { (four) (fo: }(r))}$ to replace for $\left(f_{o}:(r)\right)$. The concept that is taken as signified in the text above is to (tu:) and $\underline{4(f a:(r)}$ are represented by the symbol 2 and 4 . Those pairs have the same pronunciations.

2. Letter
a. Text
: U'll scan your pic and sent 2 my email
Meaning : you will scan picture and sent to my email.
b. Text : I just chat with $\mathrm{U}$
Meaning : I just chat with you
c. Text
: R U fasting 2day?
Meaning : are you fasting today?
d. Text : Happy b'day 2 U, wishing U'll b better and better
e. Text : Can $U$ help me pls/plz... I need $\mathrm{u}$ information about that program. about that program?
Meaning : Can you help me please! I need you information
f. Text : Do U have BF
Meaning : Do you have boyfriend
g. Text : Do U have GF
Meaning : Do you have girlfriend
h. Text : Btw... how about ur job?
Meaning : By the way... how about your job?
i. Text $\quad$ : B'careful on the way...
Meaning : be careful on the way
j. Text : I'll help U a s a p...
Meaning : I will help you as soon as possible
k. Text : U'R welcome
Meaning : you are welcome
1. Text : I GTG now
Meaning : I go to go now

REGISTER, VOL. 2, No. 1, JUNE 2009 


$\begin{array}{cl}\text { m. Text } & : \text { Hey, R U OK } \\ \text { Meaning } & : \text { Hey, are you Ok? } \\ \text { n. Text } & : \text { Thx a lot } \\ \text { Meaning } & : \text { Thanks a lot } \\ \text { o. Text } & : \text { I luv U or I L U } \\ \text { Meaning } & : \text { I love you } \\ \text { p. Text } & : \text { Asl pls } \\ \text { Meaning } & : \text { age, sex, location, please. } \\ \text { q. Text } & : \text { BRB... } \\ \text { Meaning } & : \text { Be right back } \\ \text { r. Text } & : \text { I c } \\ \text { Meaning } & : \text { I see } \\ \text { s. Text } & : \text { WB... } \\ \text { Meaning } & : \text { Welcome back } \\ \text { t. Text } & : \text { JK } \\ \text { Meaning } & : \text { Just Kidding } \\ \text { u. Text } & : \text { HAND.. } \\ \text { Meaning } & : \text { Have a nice day } \\ \text { v. Text } & : \text { CUL } \\ \text { Meaning } & \text { : See you later }\end{array}$

Analysis : U'll (ju:l) is used to replace the word you'll. It has the same concept in the use of several letter such as $\underline{U}$ to replace $\underline{y o u}, \underline{R}$ to replace are, $\underline{B(b i:)}$ or b to replace $\underline{b e}, \underline{C}$ to replace see, and $\underline{N}$ or $\mathrm{n}$ to replace and. It is also used in other form of word such as abbreviation. The word such as $\underline{B F}$ used to replace boyfriend; $\underline{G F}$ is used to replace girlfriend, $\underline{A S L}$ from age, sex, and location; $\underline{I L U}$ from I love you, $\underline{G T G}$ from got to go, $\underline{A S A P}$ from as soon as possible, $\underline{B R B}$ to replace be right back, $J K$ to replace just kidding, $\underline{W B}$ to replace welcome back, $\underline{H A N D}$ to replace have a nice day, and $\underline{C U L}$ to replace see you later.

3. Number and Letter

a. Text : Don't angry with me. I just want $2 \mathrm{~b}$ ur best friend

Meaning : Don't angry with me. I just want to be your best friend

REGISTER, VOL. 2, No. 1, JUNE 2009 
b. Text $\quad$ : B4 come there, U must come to Salatiga first

Meaning : Before I come there, you must to Salatiga first

c. Text : I luv U coz 4JJ1

Meaning : I love you because Allah.SWT

d. Text : Sorry, I'm L8

Meaning : sorry, i'm late

e. Text : I just wan2 know

Meaning : I just want to know

f. Text : There is no 1 in channel room

Meaning : There is no one channel room

g. Text : GR8

Meaning : Great

h. Text : L8R

Meaning : Later

i. Text : U1

Meaning : you first

j. Text :W8

Meaning : Wait

k. Text : B4 N

Meaning : Bye for now

1. Text : U2

Meaning : You too

Analysis : this is the part where the chatters combine the use of number and letter as their symbol in their chatting. Those symbols used as signifiers to replace certain words. Those words are $\underline{2 b}$

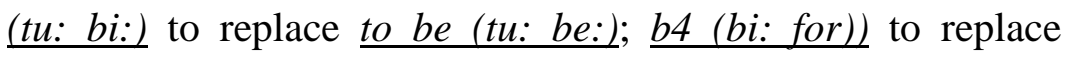
before (bi: for)); $\underline{4 J J I}$ to replace the arabic letter of Allah because they have the same form (but some people don't agree with this writing style); $\underline{L 8(L+\text { eight (eit)) to replace late }}$ (leit); wan2 (won: tu:) to replace want to; $\underline{\text { nol }}$ to replace $\underline{\text { no }}$ one; $G R 8(G R+$ eight (eit) to replace great (greit); $L 8 R(L+$ eight $($ eit $)+r)$ to replace later; $\underline{U 1}$ to replace you first $; \underline{W 8(W}$ + eight (eit)) to replace wait (weit); $\underline{B 4 N}$ to replace bye for $\underline{n o w}$; and the last one, $\underline{U 2}$ to replace you, too. Those 
combinations of number and letter are used mostly as they have the same pronunciation with the referred words.

\section{Punctuation mark/emoticons}
a. Text : :-)
Meaning : smilling or happy
b. Text : :-(
Meaning : Frowning or sad
c. Text : :-p
Meaning : Sticking tongue out.
$\begin{array}{ll}\text { d. Text } & : \text { :-D } \\ \text { Meaning } & : \text { Laughing }\end{array}$
e. Text : :-O
Meaning : Shocked
f. Text : :-C
Meaning : very sad or very Unhappy
g. Text : ;-)
Meaning : Winking or says just kidding.
h. Text : ;-))
Meaning : really happy and big smile
i. Text : :
Meaning : Crying, feel sad
j. Text : |-)
Meaning : feel shy, or give unique smile like he he he
k. Text : (-_-)
Meaning : secret smile
1. Text : ^^^
Meaning : Very kind and welcome to chatting partner
m. Text : :-|
Meaning : Grim
n. Text $\quad$ : $8-\mathrm{O}$
Meaning : Oh my god

Analysis : The next part of the research in the use of symbols in chatting is the use of punctuation marks or widely known as emoticons. These symbols are used to express the feelings of the chatters 
because they cannot see the face each other. Those emoticons are resulted from the combination of certain punctuation marks. The uses of those symbols are such as :-) or :) to express happiness and nice smile; the symbol of :-( or :( used as the expression of feeling frowning or sad; the symbol of :-P or $: \mathrm{P}$ as the signifier that the chatter are sticking tongue out; the symbol of :-D to express the mouth form when the chatters laughing; the symbol of :-O used to express get surprise or say 'wow'; the symbol :-C to describe the feeling of very sad or unhappy; the symbol ;-) to express that the chatters are winking or say 'just kidding'; the signifier :-)) to express of really happy; the signifier : to describe that they feel bad or crying; the signifier $\mid-$ ) to describe that they feel shy and give unique smile like 'hehehe'; the signifier (-_-) used to express secret smile; the signifier ${ }^{\wedge} \_\wedge$ to show that they are very kind and very welcome to the partner chatting; the symbol :- $\mid$ to describe that the chatters grim; and the last signifier 8-O to show that the chatters feel shock and say 'oh my God!'.

\section{Conclusion}

The writer attempts to explore the semiology deeper, especially the symbol used on internet chatting. In the language, Saussure as founder of linguistic and semiotics explain that symbol as one unity cannot be separated from two parts; they are signifier to explain the form and expression, and signified to explain the concept or meaning. To look far at the relation of these symbols, Saussure argues that it needs social conventional, that arrange the combination of symbols and the meaning.

In the internet chatting, text, the chatters used some symbols, they are number, letter, combine number and letter, and the last is emoticons or smiley. The example of the symbol number, consist 2 and 4 . For the letter 
consist of R, U, b, Ur, ASL, btw, and so on. For emoticons consist of :-), :$\left.(,:-\mathrm{P},:-\mathrm{D},:-\mathrm{C}, ;-),:-)),: \sim, \mathrm{L}^{-}\right),(---),{ }_{-}{ }^{\wedge},:-/$, and $8-\mathrm{O}$.

Those symbols have different meaning or references with different interpreters because they can be interpreted in denotative level as signifier or in connotative level as signified. To interpret as signifier the symbols appear as literal meaning or the real meaning of the symbols and to interpret as signified the symbols refer to personal associations or more open to interpretation. To know the meaning as signified, it is important to know the meaning signifier, because the meaning of signifier and signified have the relationship each other and cannot be separated.

\section{References}

Fiske, John. 1990. Introduction to Communication Studies. Great Britain: Guerensey Press.

Victoria, Fromkin. 1992. An Introduction to Sociolinguistic, $2^{\text {nd }}$ Edition. Oxford: Black Well Publisher

Moleong. 1983. Metodologi Penelitian Kualitatif. Bandung: Remaja Karya. http://www.abber.ac.uk/media/document/S4B/semiotic.html www.wikipedia.com 